\title{
Determination of the Phthalocyanine Textile Dye, Reactive Turquoise Blue, by Electrochemical Techniques
}

\author{
Marly E. Osugi, Patrícia A. Carneiro and Maria Valnice B. Zanoni* \\ ${ }^{a}$ Instituto de Química, Universidade Estadual Paulista, CP 355, 14801-970 Araraquara - SP, Brazil
}

\begin{abstract}
Azul turquesa 15 (AT15) é um corante reativo amplamente utilizado na indústria têxtil para colorir fibras naturais. A presença destes corantes no efluente e rejeito industrial é de considerável interesse devido a problemas ecotoxicológicos e ambientais. A redução eletroquímica deste corante foi investigada em solução aquosa usando voltametria cíclica, eletrólise em potencial controlado e voltametria de redissolução catódica. As melhores condições experimentais para descoloração de solução do corante por eletrólise em potencial controlado foram obtidas em meio alcalino. Usando voltametria de redissolução catódica, a curva analítica foi obtida em um intervalo de concentração de $5,00 \times 10^{-8} \mathrm{~mol} \mathrm{~L}^{-1}$ a $1,00 \times 10^{-6} \mathrm{~mol} \mathrm{~L}^{-1}$ de AT15 em pH 4,0, usando tempo de acúmulo de 180 e $240 \mathrm{~s}$ e potencial de acúmulo de $0,0 \mathrm{~V}$. O método proposto foi aplicado na determinação direta do corante em água de torneira e efluente da indústria têxtil.
\end{abstract}

Turquoise blue 15 (AT15) is a reactive dye widely used in the textile industry to color natural fibers. The presence of these dyes in effluent and industrial wastewater is of considerable interest due ecotoxicological and environmental problems. The electrochemical reduction of this dye has been investigated in aqueous solution using cyclic voltammetry, controlled potential electrolysis and cathodic stripping voltammetry. Optimum conditions for dye discoloration by controlled potential electrolysis use an alkaline medium. Using cathodic stripping voltammetry a linear calibration graph was obtained from $5.00 \times 10^{-8} \mathrm{~mol} \mathrm{~L}^{-1}$ to $1.00 \times 10^{-6} \mathrm{~mol} \mathrm{~L}^{-1}$ of AT15 at $\mathrm{pH} 4.0$, using accumulation times of 180 and $240 \mathrm{~s}$ and an accumulation potential of $0.0 \mathrm{~V}$. The proposed method was applied in direct determination of the dye in tap water and in textile industry effluent.

Keywords: Turquoise Blue 15, reduction of phthalocyanines, reactive dyes, electroanalysis

\section{Introduction}

Textile industry wastewater is a complex mixture of unconsumed dyes, surfactants and sometimes traces of metals. ${ }^{1,2}$ Once in the environment, certain dyes have the potential to form carcinogenic breakdown products, ${ }^{3-5}$ whilst concerns have been raised over the toxicity of certain metal complex dyes. ${ }^{6}$

The variety of physical chemistry properties of each class of dyes and the introduction of several other chemicals during the dyeing process, such as dispersing agents, salts and many other organic compounds, make the available analytical methods usually inefficient, costly and not adaptable on its determination in a wide range of dye concentrations. Due to increasingly rigorous environmental legislation, the textile industry is seeking to develop effective, rapid and reliable analytical methods for

\footnotetext{
* e-mail: boldrinv@iq.unesp.br
}

evaluating unfixed dyes, with sufficient detectability to quantify them in water samples, from different significant sampling points.

The easy electrochemical reduction of azo and antraquinone groups present in the most reactive dyes has been successfully used for dye quantification. ${ }^{7-14}$ The results have shown satisfactory selectivity and sensitivity for monitoring low levels of reactive dyes.

Turquoise blue 15 is an important commercial reactive dye based on copper-phthalocyanine as chromophore and a monochlorotriazine group as reactive site (Figure1). The main analytical methods employed for its quantitative determination are based on high performance liquid chromatography, fluorescence, and spectrophotometric methods. ${ }^{15-18}$ The redox properties of phthalocyanines are known, ${ }^{19,20}$ but electrochemical studies involving phthalocyanine dyes are not found in the literature and no electroanalytical methods have been proposed.

The present work investigates the electrochemical reduction of Turquoise blue 15 reactive dye in aqueous 
solution on mercury and glassy carbon electrodes and describes a sensitive and inexpensive method based on linear cathodic stripping voltammetry for its determination in wastewater from the textile industry.

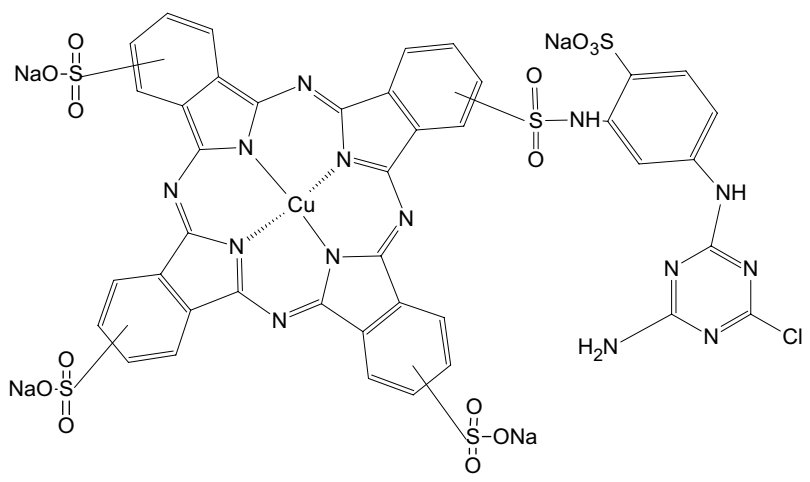

Figure 1. Molecular structure of the reactive dye turquoise blue 15 (AT15).

\section{Experimental}

The electrochemical measurements were carried out using a EG\&G PARC model 283 Potentiostat/Galvanostat controlled by Electrochemical 270 software. The cell used for cyclic voltammetric experiments was a three electrode type, with two compartments. The working electrode was a glassy carbon (PARC) disc, area $0.28 \mathrm{~cm}^{2}$, polished between experiments. A platinum auxiliary electrode and an $\mathrm{Ag} / \mathrm{AgCl}$ (saturated $\mathrm{KCl}$ ) electrode were used as counter and reference electrodes, respectively. The controlled potential electrolysis were carried out using a three compartment cell, where a Pt gauze $\left(2.5 \mathrm{~cm}^{2}\right)$, separated by a fine glass sinter, acted as cathode and a $4.0 \mathrm{~cm}^{2} \mathrm{Pt}$ gauze acted as anode in the other compartment.

Cathodic stripping voltammetric measurements were made with an EG\&G PARC model 284 Potentiostat/ Galvanostat. An EG\&G PARC model 303A was used in the Hanging Mercury Drop Electrode (HMDE) mode. The three electrode system was completed of a glassy carbon auxiliary electrode and an $\mathrm{Ag} / \mathrm{AgCl}$ (saturated $\mathrm{KCl}$ ) used as the reference electrode. All $\mathrm{pH}$ measurements were made with a Metrohm E500 pH meter with a Metrohm EA 121 glass electrode, which had been previously calibrated. Supporting electrolytes and stock solutions were prepared in demineralized water from a Milli-Q system (Millipore).

Stock solutions of metalophthalocyanine dye $(1.00 \mathrm{x}$ $10^{-3} \mathrm{~mol} \mathrm{~L}^{-1}$ ) were prepared from solid samples from Aldrich. The studies were carried out in Britton-Robinson buffer ( $0.40 \mathrm{~mol} \mathrm{~L}^{-1}$ each of acetic, o-phosphoric, and boric acids) ajusted to the required $\mathrm{pH}$ with $0.20 \mathrm{~mol} \mathrm{~L}^{-1}$ sodium hydroxide solution. The cathodic stripping voltammograms were recorded using a supporting electrolyte $(10.00 \mathrm{~mL})$ placed in a voltammetric cell and the required volume of stock solution was assed by micropipette. The general procedure for carrying out cathodic stipping was as follows. The stirrer was switched on and the solution was purged with nitrogen gas for $5 \mathrm{~min}$. The accumulation potential was then applied to a new mercury drop, whilst still stirring the solution. After a $10 \mathrm{~s}$ quiescent period, with the stirring stopped, a potential scan in the negative direction was applied. Unless otherwise stated the following parameters were used; accumulation time $30 \mathrm{~s}$, accumulation potential $0.0 \mathrm{~V}$; scan rate $50 \mathrm{mV} \mathrm{s}^{-1}$. The maximum drop size $\left(0.40 \mathrm{~mm}^{2}\right)$ and a constant stirrer speed of $1000 \mathrm{rpm}$ were used.

\section{Results and Discussion}

\section{Electrochemical reduction}

The electrochemical reduction of Turquoise blue 15 reactive dye (AT15) was investigated in B-R buffer, $2.0 \leq$ $\mathrm{pH} \leq 12.0$, at a glassy carbon electrode. Typical cyclic voltammograms for $5.00 \times 10^{-4} \mathrm{~mol} \mathrm{~L}^{-1}$ Turquoise blue 15 reactive dye in $\mathrm{B}-\mathrm{R}$ buffer at $\mathrm{pH} 4.0$ and 10.0 on a glassy carbon electrode with a scan rate of $50 \mathrm{mV} \mathrm{s}^{-1}$, are shown in Figures 2 and 3. In acidic medium, the copper phthalocyanine is reduced in only one step but exhibits two reduction waves in an alkaline medium.

In an acidic medium the peak potential $\left(\mathrm{E}_{\mathrm{p}}\right)$ of the first reduction wave is shifted towards more negative values with increasing $\mathrm{pH}$, showing a linear relationship at $2.0 \leq \mathrm{pH} \leq 6.0$ with a slope of $50.3 \mathrm{mV}$, as shown in Figure 4. In neutral and alkaline ranges $(\mathrm{pH} \geq 7.0)$ the reduction of AT15 presents two reduction steps and the peak potential exhibits a pH-independent behavior for both processes. The peak current is practically constant up to $\mathrm{pH}$ 5. Above

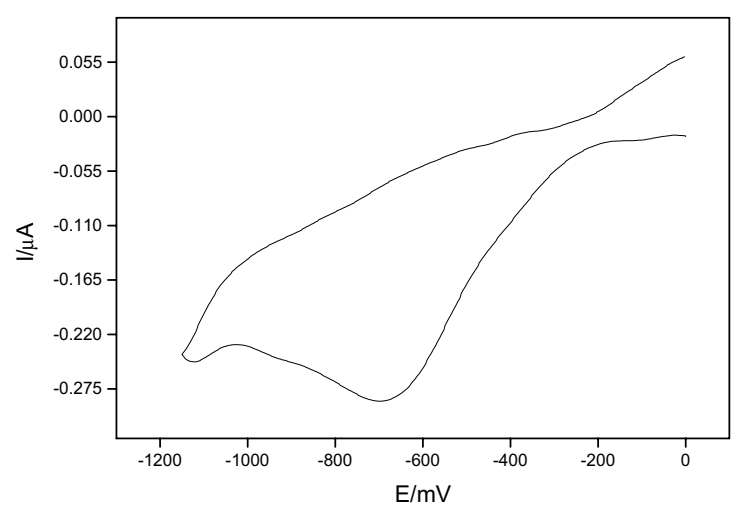

Figure 2. Cyclic voltammograms for $5.00 \times 10^{-4} \mathrm{~mol} \mathrm{~L}^{-1}$ of AT15 reactive dye in $\mathrm{B}-\mathrm{R}$ buffer, $\mathrm{pH} 4.0$, on a glassy carbon electrode; scan rate of $50 \mathrm{mV} \mathrm{s}^{-1}$. 


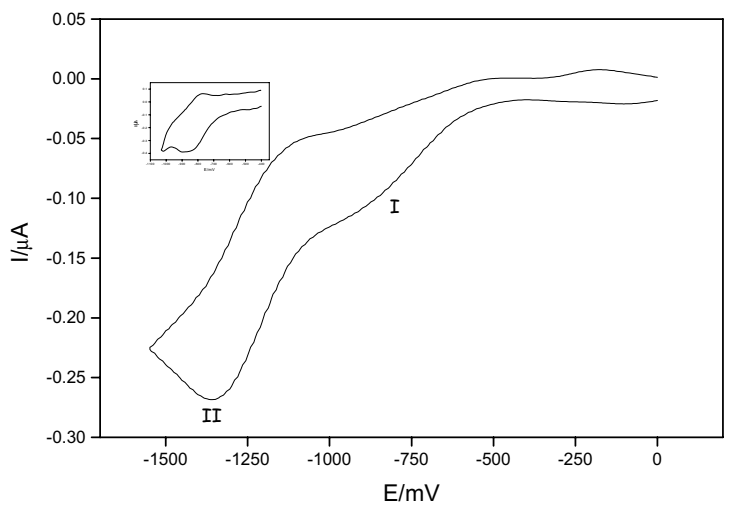

Figure 3. Cyclic voltammograms for $5.00 \times 10^{-4} \mathrm{~mol} \mathrm{~L}^{-1}$ of the AT 15 reactive dye in $\mathrm{B}-\mathrm{R}$ buffer, $\mathrm{pH} 10.0$, on a glassy carbon electrode; scan rate of $50 \mathrm{mV} \mathrm{s}^{-1}$. Inset curve: Cyclic voltammograms obtained for the first reduction peak at a scan rate of $1000 \mathrm{mV} \mathrm{s}^{-1}$.

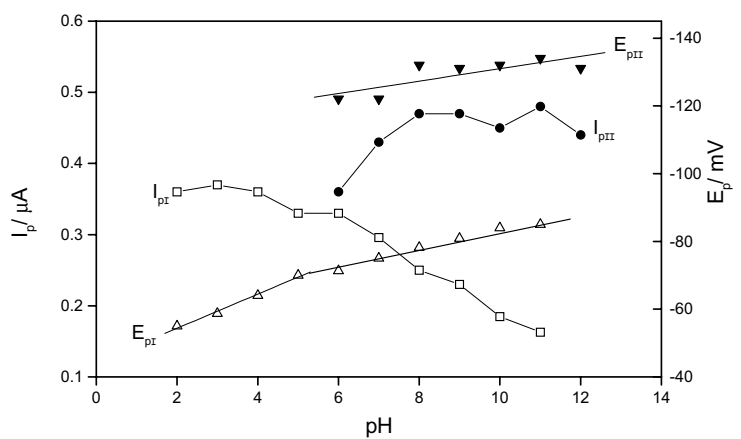

Figure 4. Effect of $\mathrm{pH}$ variation on the cathodic peak potential and peak current obtained from cyclic voltammograms of $1.00 \times 10^{-3}$ mol L ${ }^{-1}$ AT15 dye. Scan rate $=50 \mathrm{mV} \mathrm{s}^{-1}$.

$\mathrm{pH}$ 6.0, the peak current of the first wave decreases but the second one increases up to $\mathrm{pH} 8.0$, when it is almost constant at higher $\mathrm{pH}$ values. The analysis of both parameters, $\mathrm{E}_{\mathrm{p}} v s . \mathrm{pH}$ and $\mathrm{I}_{\mathrm{p}} v s . \mathrm{pH}$, indicates typical behavior expected from a protonation-deprotonation equilibrium in the molecule.

The effect of scan rate on the cyclic voltammetric behavior of AT15 in B-R buffer at pH 4.0 and $\mathrm{pH} 10.0$ was investigated from $10 \mathrm{mV} \mathrm{s}^{-1}$ to $1000 \mathrm{mV} \mathrm{s}^{-1}$. In an acidic medium no anodic peak corresponding to reoxidation of the first peak was observed at any scan rate, indicating the non-reversibility of the electrode process. The corresponding peak current was proportional to $v^{1 / 2}$, following the equation: $\left.\mathrm{Ip}(\mu \mathrm{A})=0.171+0.537 v^{1 / 2}\right)\left(v=\mathrm{mV} \mathrm{s}^{-1}\right)$, $\mathrm{R}=0.998, \mathrm{~N}=6, \mathrm{SD}=0.307$, to $\mathrm{pH}$ 4. This behavior is indicative that the process is diffusion controlled. From the linear shift to less negative potential observed in the reduction peak potential with an increase in the scan rate (10 -100 $\left.\mathrm{mV} \mathrm{s}^{-1}\right)$ the following slope was obtained: $\partial \mathrm{E}_{\mathrm{p}} / \partial \log _{v}=61 \mathrm{mV}$. The current function $\left(\mathrm{I}_{\mathrm{p}} \cdot v^{-1 / 2}\right)$ decreased when the potential scan rate was increased. These results suggest that in an acid medium dye reduction is complicated by rapid chemical reaction subsequent to charge transfer. ${ }^{21}$

In B-R buffer at $\mathrm{pH} 10.0$ the peak current of both reduction peaks (Figure 3 ) are proportional to $v^{1 / 2}$, showing that the process is diffusion controlled. The first reduction peak has an anodic peak on the reverse scan, whose current increases with scan rate, as shown in the insery voltammogram recorded at $1000 \mathrm{mV} \mathrm{s}^{-1}$ (Figure 3). The current function decreases and the peak potential shifts to anodic values when the potential scan rate is increased, indicating that the reduction step follows a mechanism involving a chemical reaction after the electron transfer. The second reduction step shows an anodic peak on the reverse scan at all scan rates and the ratio of $\mathrm{I}_{\mathrm{pa}} / \mathrm{I}_{\mathrm{pc}}$ is around 1. The $\mathrm{I}_{\mathrm{p}} v s . v^{1 / 2}$ plot is linear and the cathodic current function and peak potential are constant at all scan rates indicating that the current is diffusion controlled and the electrodic process has a reversible process.

Controlled-potential electrolysis was carried out on solutions of $1.00 \times 10^{-3} \mathrm{~mol} \mathrm{~L}^{-1}$ of AT15 dye in B-R buffer at pH 2.0; 6.0 and 10.0, using Pt gauze as cathode. In each case, the electrolysis was performed in a potential more negative than the reduction peak observed previously, by cyclic voltammograms recorded in these experimental conditions.

The current was recorded as a function of time during one hour of electrolysis and the number of electrons (n) estimated after total reduction is presented in Table 1. In an acid medium, the current decays linearly with time, the coloration change from turquoise blue to purple and the nvalues obtained from curve of I vs. t integration are always around 4 (4.44 \pm 0.35$)$. In neutral and alkaline solutions the n-values obtained after the controlled potential electrolysis at the first cathodic potential are also around $4(3.97 \pm 0.45)$ and values around 8 electrons $(7.85 \pm 0.15)$ are obtained at potential corresponding to the second reduction step, indicating that the reactive dye is reduced in two steps of 4 electrons each. The products collected at the end of electrolysis present a purple color, but this coloration disappears after some time in the presence of oxygen.

Table 1. Coulometric parameters obtained for controlled potential electrolysis of $1.00 \times 10^{-3} \mathrm{~mol} \mathrm{~L}^{-1}$ AT15 dye in B-R buffer

\begin{tabular}{rrc}
\hline $\mathrm{pH}$ & $-\mathrm{E} / \mathrm{mV}$ & $\mathrm{n}$ \\
\hline 2.0 & 50 & 4.44 \\
6.0 & 65 & 3.97 \\
6.0 & 110 & 7.85 \\
10.0 & 70 & 3.99 \\
10.0 & 110 & 8.29 \\
\hline
\end{tabular}


The results obtained indicate that the aromatic $18 \pi$ electron system of phthalocyanine, with the usual two negative charges, shows reduction of the four pyrrole groups on the macrocycle before any redox process on the central metal ion, such as $\mathrm{Cu}(\mathrm{II}),{ }^{22,23}$ as a result of the strong coordination of nitrogen bonds to the metal ion. The single irreversible wave observed in an acid medium indicates that probably the reduced product involves the displacement of metal ion from the anion radical and/or a protonation reaction, as previously reported..$^{22,24}$

In alkaline and neutral media, this chemical reaction is minimized and two redox processes are observed, probably due to successive reduction of the phthalocyanine center to anion radical (4 electrons) and dianion (4 electrons). The discoloration of the dye solution was observed only after $5 \mathrm{~h}$ of controlled potential electrolysis using $1.00 \mathrm{x}$ $10^{-3} \mathrm{~mol} \mathrm{~L}^{-1}$ of dye, $\mathrm{pH} 10.0$ and a potential of $-1.2 \mathrm{~V}$. The spectrophotometric analysis of the product generated under these conditions are shown in Figure 5. As with other metalo-phtalocyanines, ${ }^{25}$ the absorption spectra of AT15 at $\mathrm{pH}$ 10.0 B-R buffer present an intense band around 610 and $670 \mathrm{~nm}$ due to the $\pi \rightarrow \pi^{*}$ transition, usually referred to Q-bands. Also, the copper-phthalocyanine dye has a Bsoret band in the range of $350 \mathrm{~nm}$ and an L-band around $270 \mathrm{~nm}$. The decreasing in the absorbance is clear in the UV-VIS spectrum of catholytes removed at each 1 hour of electrolysis, as shown in Figure 5. The total electrolysis consumes 16 electrons $(\mathrm{Q}=46.25 \mathrm{C})$ and promotes nearly $100 \%$ removal of colour after $5 \mathrm{~h}$ of electrolysis. The dye discoloration was followed and graphs of $\log \left(\mathrm{A}_{t} / \mathrm{A}_{0}\right) v s$. time present a linear relationship indicating that dye degradation followed a first order relationship. In the case of the textile industry, metals such as copper are believed to be readily released from copper-complexed phthalocyanine dyes ${ }^{23,24}$ during the dyeing processes that

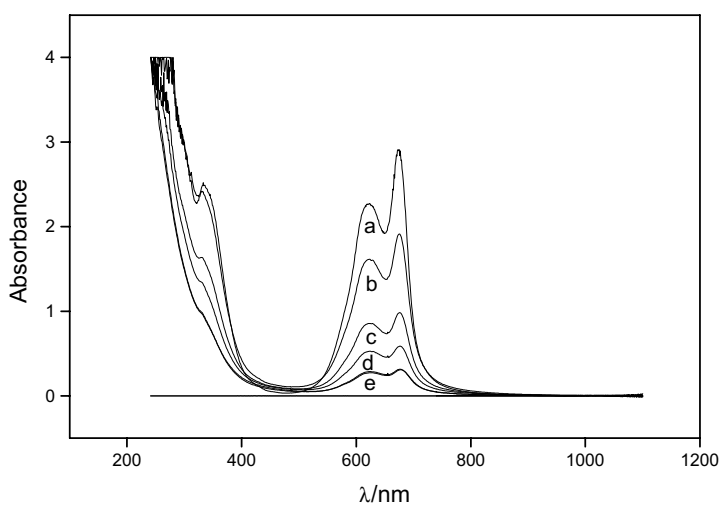

Figure 5. The absorption spectra of $5.00 \times 10^{-5} \mathrm{~mol} \mathrm{~L}^{-1}$ original and electrolyzed AT15 dye in B-R, buffer pH 10.0, (a) before electrolysis; (b-e) - after controlled potential electrolysis at $\mathrm{E}=-1.2 \mathrm{~V}$ with aliquots analyzed each $60 \mathrm{~min}$. require alkaline conditions. So, the results indicate that the radical species formation (acid medium) or copper release observed under alkaline conditions do not stimulate the use of controlled potential electrolysis as a colour removal method for metalo-phthalocyanine dyes.

Although copper phthalocyanine dyes are electrochemically active, cyclic voltammetry on a glassy carbon electrode is not sensitive enough for determining the reactive dye at low levels. Thus, cathodic stripping voltammetry was investigated with the aim to develop a simple procedure for the determination of copper phthalocyanine in aqueous solution and industrial effluent.

\section{Analytical applications}

The results of cathodic stripping voltammetry were obtained using the AT15 adsorption step on an HMDE from stirred solutions. Typical cyclic voltammograms obtained for $1.00 \times 10^{-6} \mathrm{~mol} \mathrm{~L}^{-1}$ of AT15 dye in B-R buffer, $\mathrm{pH} 4.0$, scan rate of $50 \mathrm{mV} \mathrm{s}^{-1}$ and an accumulation time of $0 \mathrm{~s}$ and $30 \mathrm{~s}$ are shown in curves (a) and (b) of Figure 6. The reduction of AT15 previously adsorbed on a mercury electrode presents three cathodic peaks. The second and third peaks (II and III) are similar to those observed in voltammetric studies on glassy carbon and are attributed to the reduction of the ligand. Nevertheless, at all $\mathrm{pH}$ values an extra peak was observed at a less negative potential (peak I) on stripping voltammograms, which could be attributed to the reduction of the metal center, not seen without pre-accumulation. These results suggest that the prior adsorption step of the dye on the mercury electrode could stabilize the coordination bond of metal and the phthalocyanine ring, leading to reduction of both $\mathrm{Cu}(\mathrm{II})$ and the pyrrole ring.

A systematic study of various experimental parameters

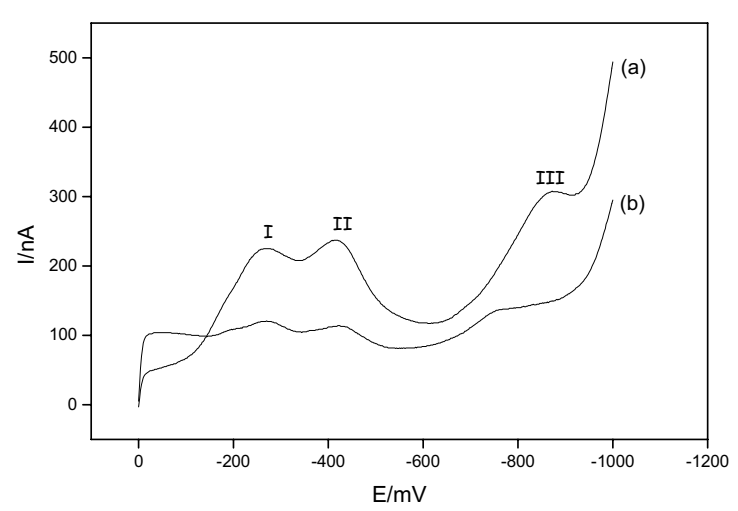

Figure 6. Cathodic stripping voltammograms obtained for $1.00 \mathrm{x}$ $10^{-6} \mathrm{~mol} \mathrm{~L}^{-1}$ AT15 dye in B-R buffer, $\mathrm{pH} 4.0 ; v=100 \mathrm{mV} \mathrm{s}^{-1} ; \mathrm{E}_{\mathrm{ac}}=0.0$ $\mathrm{V} ; \mathrm{t}_{\mathrm{ac}}=0 \mathrm{~s}($ Curve $\mathrm{b})$ and $\mathrm{t}_{\mathrm{ac}}=30 \mathrm{~s}$ (Curve a) on a hanging mercury electrode. 
such as $\mathrm{pH}$, scan rate, accumulation time and accumulation potential was carried out. The influence of $\mathrm{pH}$ on the peak current was investigated from $2.0 \leq \mathrm{pH} \leq 10.0$. All the peaks present maximum sensitivity at $4.0<\mathrm{pH}<8.0$, indicating preferential adsorption of the phthalocyanine dye under these conditions. Both peaks at less negative potentials at pH 6.0 were chosen as optimum conditions to monitor the dye.

The effect of accumulation potential $\left(E_{a c}\right)$ on the stripping current at potentials between +0.1 and $-0.25 \mathrm{~V}$ for solutions of $1.00 \times 10^{-6} \mathrm{~mol} \mathrm{~L}^{-1}$ AT15 in B-R buffer, $\mathrm{pH}$ 4.0, using an accumulation time of $30 \mathrm{~s}$ were evalueted. The first reduction peak is absent at $\mathrm{E}_{\mathrm{ac}}$ of less positive potential than $+0.05 \mathrm{~V}$, but all peaks present high intensity at an accumulation potential of $0.0 \mathrm{~V}$, which was adopted to pre-concentrate AT15 dye. The effect of accumulation time $\left(\mathrm{t}_{\mathrm{ac}}\right)$ was investigated for $1.00 \times 10^{-6} \mathrm{~mol} \mathrm{~L}^{-1}$ AT15 in B$\mathrm{R}$ buffer, $\mathrm{pH} 4.0$, using $\mathrm{t}_{\mathrm{ac}}$ of $0 \mathrm{~s}$ to $180 \mathrm{~s}, \mathrm{E}_{\mathrm{ac}}$ of $0.0 \mathrm{~V}$ and a scan rate of $50 \mathrm{mV} \mathrm{s}^{-1}$. The height of the three reduction peaks increased rectilinearly with accumulation time between $0-80 \mathrm{~s}$ following the equations : $\mathrm{I}_{\mathrm{p}}(\mathrm{nA})=41.7+$ $0.514 \mathrm{t}(\mathrm{t}=\mathrm{s}), \mathrm{R}=0.998, \mathrm{~N}=6, \mathrm{SD}=1.07$ for peak $\mathrm{I} ; \mathrm{I}_{\mathrm{p}}(\mathrm{nA})$ $=40.8+0.389 \mathrm{t}(\mathrm{t}=\mathrm{s}), \mathrm{R}=0.994, \mathrm{~N}=6, \mathrm{SD}=1.31$ for peak II and $I_{p}(n A)=53.2+0.553 t(t=s), R=0.993, N=5, S D=$ 1.82 for peak III. Above this time the current reaches a plateau because of saturation of the electrode. Using $1.00 \times 10^{-7} \mathrm{~mol} \mathrm{~L}^{-1}$ of AT 15 dye, the relationship of $\mathrm{I}_{\mathrm{p}} v \mathrm{~s} . \mathrm{t}_{\mathrm{ac}}$ was linear up to $3 \mathrm{~min}$, indicating that the concentration and accumulation time are related parameters. The peak current of all peaks obtained from $1.00 \times 10^{-6} \mathrm{~mol} \mathrm{~L}^{-1}$ AT 15 dye in B-R buffer at $\mathrm{pH} 4.0$, accumulated at $0.0 \mathrm{~V}$ during $30 \mathrm{~s}$, increased linearly with scan rate from 10 to $500 \mathrm{mV} \mathrm{s}^{-1}$, as is expected for a adsorption controlled process.

Following the best experimental conditions previously optimized analytical graphs were obtained for the first reduction step from voltammograms recorded at an accumulation time of $180 \mathrm{~s}$ from $1.00 \times 10^{-8} \mathrm{~mol} \mathrm{~L}^{-1}$ to $1.00 \times 10^{-7} \mathrm{~mol} \mathrm{~L}^{-1}$. The linear graph follows the equation: $\mathrm{I}_{\mathrm{p}}(\mathrm{nA})=-0.41+2.54 \times 10^{8} \mathrm{C}\left(\mathrm{C}=\mathrm{mol} \mathrm{L}^{-1}\right), \mathrm{R}=0.998, \mathrm{~N}=5$, $\mathrm{SD}=0.706$ for peak I. For peaks II and III, a linear relationship is obtained from $7.50 \times 10^{-7} \mathrm{~mol} \mathrm{~L}^{-1}$ a $1.75 \times 10^{-6}$ mol L-1, following the equations : $\mathrm{I}_{\mathrm{p}}(\mathrm{nA})=2.03+6.85 \times 10^{7}$ $\mathrm{C}\left(\mathrm{C}=\mathrm{mol} \mathrm{L}^{-1}\right), \mathrm{R}=0.997, \mathrm{~N}=6, \mathrm{SD}=3.91$ for peak II and $\mathrm{I}_{\mathrm{p}}(\mathrm{nA})=3.49+1.03 \times 10^{7} \mathrm{C}\left(\mathrm{C}=\mathrm{mol} \mathrm{L}^{-1}\right), \mathrm{R}=0.995, \mathrm{~N}=6$, $\mathrm{SD}=7.35$ for peak III.

The repeatability of the method was determined by making successive measurements on five solutions of $5.00 \times 10^{-7} \mathrm{~mol} \mathrm{~L}^{-1}$ at $\mathrm{pH} 4.0$. Relative standard deviations of $2.05 \% ; 1.36 \%$ e $1.75 \%$ were obtained for peaks I, II and III, respectively. Detection limits of $8.34 \times 10^{-9} \mathrm{~mol} \mathrm{~L}^{-1}$; $1.69 \times 10^{-7} \mathrm{~mol} \mathrm{~L}^{-1}$ and $1.50 \times 10^{-7} \mathrm{~mol} \mathrm{~L}^{-1}$ were calculated
(LD = 3 x SD/ slope) for peaks I; II and III, respectively.

The findings show that cathodic stripping voltammetry can be an accurate, simple and quick technique to determine traces of AT 15 by monitoring the chromophoric system. Taking into consideration the interest in sensitive techniques to monitor and identify low levels of phthalocyanine dyes, application of stripping voltammetry was investigated for the determination of AT15 dye in tap water and in an effluent sample from a textile plant.

Typical voltammograms obtained for $20.00 \mathrm{~mL}$ of tap water in B-R buffer, $\mathrm{pH} 6.0$, spiked with $1.00 \times 10^{-7} \mathrm{~mol} \mathrm{~L}^{-1}$ AT15 dye are shown in curve A of Figure 7 . The corresponding voltammetric curves obtained $\left(\mathrm{t}_{\mathrm{ac}}=60 \mathrm{~s}\right)$ showed the characteristic peaks at $-0.26 \mathrm{~V}$ and $-0.43 \mathrm{~V}$, whose peak currents increased after standard additions of $10.0 \mu \mathrm{L}$ of a $1.00 \times 10^{-4} \mathrm{~mol} \mathrm{~L}^{-1}$ solution of the dye, following the equations: $\mathrm{I}_{\mathrm{p}}(\mathrm{nA})=5.12+5.95 \times 10^{7} \mathrm{C}\left(\mathrm{C}=\mathrm{mol} \mathrm{L}^{-1}\right)$, $\mathrm{R}=0.994, \mathrm{~N}=5, \mathrm{SD}=1.21\left(\mathrm{t}_{\mathrm{ac}}=30 \mathrm{~s}\right)$ and $\mathrm{I}_{\mathrm{p}}(\mathrm{nA})=8.01+$ $8.32 \times 10^{7} \mathrm{C}\left(\mathrm{C}=\mathrm{mol} \mathrm{L}^{-1}\right), \mathrm{R}=0.999, \mathrm{~N}=5, \mathrm{SD}=0.626$ $\left(t_{a c}=60 \mathrm{~s}\right)$. A recovery of $100 \%$ was obtained.
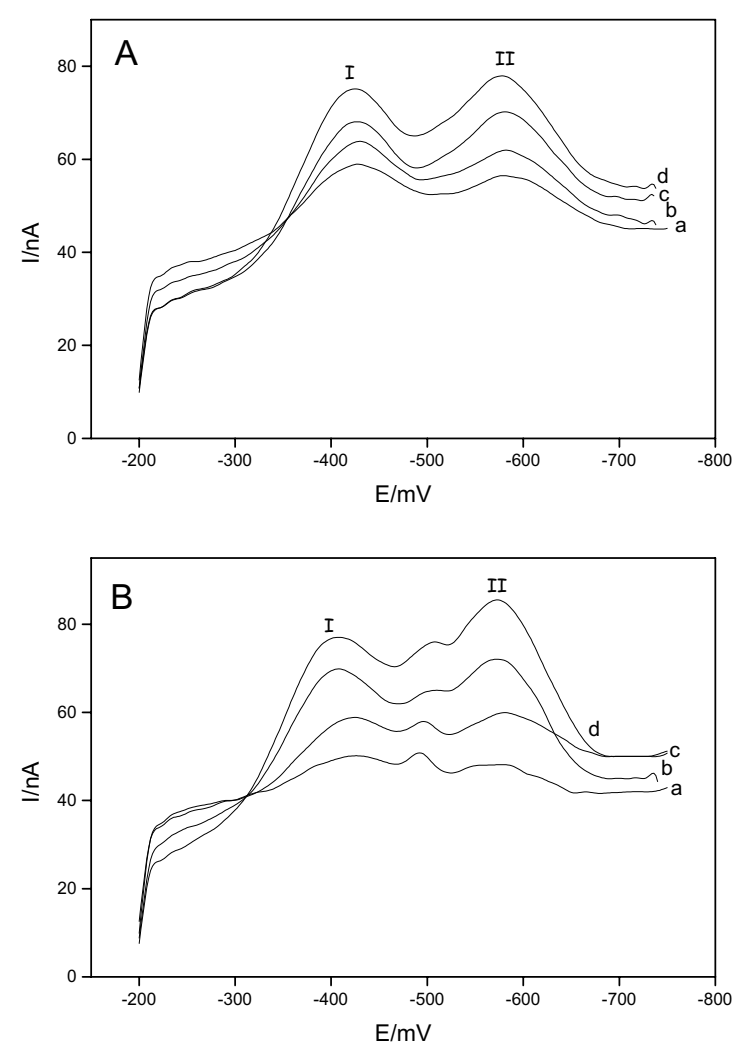

Figure 7. A) Cathodic stripping voltammograms obtained for tap water spiked with $1.00 \times 10^{-7} \mathrm{~mol} \mathrm{~L}^{-1}$ AT15 dye in B-R buffer, $\mathrm{pH} 4.0$; $v=100 \mathrm{mV} \mathrm{s}^{-1} ; \mathrm{E}_{\mathrm{ac}}=0.0 \mathrm{~V} ; \mathrm{t}_{\mathrm{ac}}=60 \mathrm{~s}$, before (a) and after successive standard additions of $1.00 \times 10^{-7} \mathrm{~mol} \mathrm{~L}^{-1}$ AT15 dye (b-d); B) Cathodic stripping voltammograms obtained for samples of textile industry effluent spiked with $1.00 \times 10^{-7} \mathrm{~mol} \mathrm{~L}^{-1}$ AT15 dye in B-R buffer, $\mathrm{pH}$ $4.0 ; v=100 \mathrm{mVs}^{-1} ; \mathrm{E}_{\text {ac }}=0.0 \mathrm{~V} ; \mathrm{t}_{\mathrm{ac}}=60 \mathrm{~s}$ before (a) and after successive standard addition of $1.00 \times 10^{-7} \mathrm{~mol} \mathrm{~L}^{-1}$ AT15 dye (b-d). 
Effluent collected from a sample holding tank spiked with $1.00 \times 10^{-7} \mathrm{~mol} \mathrm{~L}^{-1}$ of AT15 dye was diluted 1.00:20.00 $\mathrm{mL}$ in B-R buffer $\mathrm{pH}$ 6.0. The stripping voltammograms recorded with $60 \mathrm{~s}$ of accumulation time are exhibited in curve B of Figure 7. In addition to the reduction peak attributed to the copper-phthalocyanine dye it is possible to detect an extra peak at $-0.5 \mathrm{~V}$ due reduction of azo dyes also presents in the effluent sample. AT15 dye concentration in the effluent was then calculated by means of standard additions of stock solution, whose two peaks increase following the equations: $\mathrm{I}_{\mathrm{p}}(\mathrm{nA})=5.78+5.60 \times 10^{7}$ $\mathrm{C}\left(\mathrm{C}=\mathrm{mol} \mathrm{L}^{-1}\right), \mathrm{N}=5, \mathrm{SD}=1.48$ and $\mathrm{I}_{\mathrm{p}}(\mathrm{nA})=10.1+$ $10.4 \times 10^{7} \mathrm{C}\left(\mathrm{C}=\mathrm{mol} \mathrm{L}^{-1}\right) \mathrm{N}=6, \mathrm{SD}=2.29$. The recovery obtained was around $100 \%$. The results indicate that copper-phthalocyanine dye can be quantified in low concentration in effluent samples or in tap water using the stripping voltammetric method.

\section{Conclusion}

Our findings indicate that the reduction of reactive turquoise blue AT 15 occurs via a four electron transfer to the pyrrole rings, generating an anion radical stable enough to be detected only in alkaline medium. Two redox processes involving 4 reversible transfer electrons forming the dianion are observed. Total discoloration of a 1.00x $10^{-3} \mathrm{~mol} \mathrm{~L}^{-1}$ dye solution was observed only after $5 \mathrm{~h}$ of electrolysis in B-R buffer, but the possible loss of copper makes the method not suitable for effluent treatment.

In addition, our results have also shown that cathodic stripping voltammetry can be an excellent alternative for determining low concentrations of dye in tap water or effluent from the textile industry without any prior treatment. Taking into consideration that dyes need to be determined at least at the $10-50 \mu \mathrm{g} \mathrm{mL}^{-1}$ (ppb) level in water samples, ${ }^{17}$ the proposed method could be used in such samples.

\section{References}

1. Zollinger, H.; Color Chemistry, VHS: Germany, 1991.

2. Venkataraman, K.; The Chemistry of Synthetic Dyes; Academic Press: New York, 1972, vol. VI.

3. Hunger, K.; Chimia 1994, 48, 520.

4. Collier, S. W.; Storm, J. E.; Bronaugh, R. L.; Toxicol. Appl.
Pharmacol. 1993, 118, 73.

5. Zabaida, S. ;Drug Metab. Reviews 1995, 27, 497.

6. Tang, C.W.; Appl. Phys. Lett. 1986, 48, 183.

7. Zanoni, M.V.B.; Fogg, A.G. ; Barek, J.; Zima, J.; Anal. Chim. Acta 1995, 315, 41.

8. Zanoni, M.V.B.; Fogg, A.G. ; Barek, J.; Zima, J.; Anal. Chim. Acta 1997, 349, 101.

9. Fogg, A.G.; Zanoni, M.V.B.; Yusoff, A.R.H.M.; Ahmad, R.; Barek, J.; Zima, J.; Anal. Chim. Acta 1998, 362, 235.

10. Zanoni, M.V.B.; Guaratini, C. C. I; Fogg, A.G.; Microchem. J. 2002, 71, 65 .

11. Zanoni, M.V.B; Fogg, A.G.; Guaratini, C. C. I.; Dyes Pigments 2001, 50, 211.

12. Zanoni, M.V.B; Carneiro, P. A.; Ciencia Hoje 2001, $29,61$.

13. Zanoni, M.V.B.; Guaratini, C. C. I; Fogg, A.G.; Electroanalysis 2001, 13, 1.

14. Zanoni, M.V.B.; Carneiro, P. A.; Furlan, M.; Guaratini, C. C. I; Fogg, A.G.; Anal. Chim. Acta 1999, 385, 385.

15. Conneely, A.; Smyth, W. F.; McMullan, G.; FEMS Microbiol. Lett. 1999, 179, 333.

16. Schofield, J.; Asai, M.; J. Chromatogr. 1997, 770, 345.

17. Rui J.; Schousee I.; Barceló D.; Rafols C.; Trends Anal. Chem. 1997, 16, 105.

18. Smyth, W.F.; McClean, S.; O’Kane, E.; Banat, I.; McMullan, G.; J. Chromatogr. A 1999, 854, 259.

19. Rollmann L.D.; Iwamoto, R.T.; J. Am. Chem. Soc. 1968, 90, 1455.

20. Irvine, J.T.S.; Eggins B.R.; Grimshaw J.; J. Electroanal. Chem. 1989, 271, 161.

21. Brown, E.R.; Large, R. F. In Physical Methods of Chemistry: Part IIA-Electrochemical Methods; Weissberger, A.; Rossiter, B.W. eds., Wiley: New York, 1971, p. 423.

22. Leznoff C.C.; Lever, A. B. P.; Phthalocyanines: Properties and Applications, VCH: Weiheim, 1993, p. 3.

23. Ozkaya, A. R.; Gurek, A. G.; Gul, A.; Bekaroglu, O.; Polyhedron 1997, 16, 1877.

24. Baughman, G. L.; Dyes Pigments 2001, 48, 179.

25. Agirtas, S.; Ion, R. M.; Bekaroglu, O.; Mat. Sci. Eng. C-Bio. S. 2000, 7, 105.

Received: February 4, 2003

Published on the web: August 14, 2003

FAPESP helped in meeting the publication costs of this article. 